\title{
The Moderating Impact of Organizational Identity Strength between Strategic Improvisation and Organizational Memory and Their Effects on Competitive Advantage
}

\author{
Siyuan $\mathrm{Yu}^{1}{ }^{1} *$, Yang Zhang ${ }^{1}$, Jin $\mathrm{Yu}^{1}{ }^{1}$, Xuanzhi Yang ${ }^{2}$ and Abbas Mardani ${ }^{3, * \mathbb{D}}$ \\ 1 Business School, Hohai University, Nanjing 211100, China; zyang@hhu.edu.cn (Y.Z.); yujin513@126.com (J.Y.) \\ 2 School of Management, Jiangsu University, Zhenjiang 211100, China; yangkaihan@hhu.edu.cn \\ Muma College of Business, University of South Florida, Tampa, FL 33620, USA \\ * Correspondence: yusiyuan@hhu.edu.cn (S.Y.); abbasmardani@mail.usf.edu (A.M.)
}

\section{check for}

updates

Citation: Yu, S.; Zhang, Y.; Yu, J.; Yang, X.; Mardani, A. The Moderating Impact of Organizational Identity Strength between Strategic Improvisation and Organizational Memory and Their Effects on Competitive Advantage. Sustainability 2021, 13, 3207. https:// doi.org/10.3390/su13063207

Academic Editors: Marc A. Rosen and Barbara Scozzi

Received: 28 December 2020

Accepted: 10 March 2021

Published: 15 March 2021

Publisher's Note: MDPI stays neutral with regard to jurisdictional claims in published maps and institutional affiliations.

Copyright: (c) 2021 by the authors. Licensee MDPI, Basel, Switzerland. This article is an open access article distributed under the terms and conditions of the Creative Commons Attribution (CC BY) license (https:// creativecommons.org/licenses/by/ $4.0 /)$.
Abstract: In the ever-changing environment, companies are often required to adopt improvised responses to certain unpredicted events and sometimes need to improvise strategically to sustain or thrive. However, the mechanism between strategic improvisation and competitive advantage is understudied. In this study, we try to unveil the mechanism by proposing a moderated mediation model investigating the relationships among strategic improvisation, organizational memory, organizational identity strength, and competitive advantage. Using survey data collected among top managers and members of funding teams in Jiangsu Province, China, we find that strategic improvisation is positively related to competitive advantage, and most importantly, this relationship is partially mediated by organizational memory. However, the moderating effect of organizational identity strength on the relationship between strategic improvisation and organizational memory is not proven. We contribute to the existing literature by making up for the deficiency of the traditional resource-based view to some extent, enhancing the understanding of strategic improvisation, and contributing to achieving sustainable development goals 8 and 12. We also offer some practical suggestions to top managers in terms of cultivating improvising learning as well.

Keywords: strategic improvisation; competitive advantage; organizational learning; organizational memory; organizational identity strength

\section{Introduction}

Scholars argue that the traditional design-plan-execute process is not effective enough to help organizations navigate in the unpredictable turbulent environment [1,2]. Besides, organizations with little planning are not necessarily less profitable than organizations with plans based on sustainable development [3]. Therefore, organizational improvisation becomes a legitimate means for sustainable companies to deal with unforeseen threats and opportunities $[4,5]$. To take it one step further, companies in a dynamic environment improvise for tactical purposes and take strategic improvisation action when necessary $[6,7]$. Strategic Improvisation (SI) can be understood as the processes where planning and action are strategically exhibited at the emergence of behavior [8,9], and it is a legitimate alternative to make and execute strategies.

In the VUCA (volatility, uncertainty, complexity, and ambiguity) environment, corporate sustainability has been understood as a key aspect for organizations [10]. The socio-economic view believes that in order to sustain itself in the market, firms must bear social obligations and the resulting social costs. They must protect social welfare by nonpolluting, non-discriminatory, and non-deceptive advertising. They must integrate into their communities, and funding charitable organizations will play an active role in improving society [11]. Some SI adopted by companies could bring competitive advantages [7,12]. 
Others, however, argue that improvising actions have a dark side that could be catastrophic to organizations [13] because improvising actions are not inherently good or bad [14].

With the body of work on SI growing, the knowledge gap remains, namely why SI acts as a double-edged sword. The relationship between SI and competitive advantage could be affected by other intervening factors. Previous studies mostly pay attention to analyzing external factors that could affect SI outcomes, such as environmental dynamism and information flow [15]. In contrast, the internal mediating mechanism that preserves the positive effects of SI is understudied. To be specific, the research questions of this study are: what is the mechanism through which SI contributes to competitive advantages, and what contingency factors would these positively reinforce the relationship for sustainable development?

Recent works point out that improvisation is a form of a real-time organizational learning activity $[16,17]$, and it is performed in daily interactions $[18,19]$. Yet as a set of skills that can be trained by organizational leaders [20,21], little is known how it should be learned and what facilitates the process so as to lead to better performance. Alining with prior works, we adopt a learning perspective to understand SI as novel actions utilized by top managers or funding teams spontaneously to respond to unforeseen events using resources at hand under time pressure. We unpack the black box between SI and competitive advantage by proposing a moderated mediation model. From a knowledge-based viewpoint, we investigate a mediating role for organizational memory in the relationship between SI and competitive advantage. Second, based on situated learning theory, we explore the moderating effect of organizational identity strength, defined as how strong organizations hold their identity in this mediated relationship.

In this paper, we respond to the above questions by first presenting the theoretical background in which we define SI as a learning process in a sustainable way. Then, we propose five hypotheses to unpack the mechanism between SI and competitive advantage by exploring the mediating role of organizational memory and the first-stage moderator of organizational identity strength for competitive advantage. Then, the research method and data collection process are presented.

The findings of this paper demonstrate that SI has a positive influence on competitive advantage, and most importantly, this relationship is partially mediated by organizational memory. However, the hypothesis on the organizational identity strength as the moderator is not proved. The reasons why the effect is insignificant are further discussed in the discussion section. The paper contributes to the existing literature two-fold. First, theoretically, this paper makes up the deficiency of the traditional resource-based view and enriches the understanding of how companies with limited resources or capabilities gain competitive advantage by investigating the black box between SI and competitive advantage from a learning viewpoint. Second, practically speaking, by unpacking the relationship between SI, organizational memory, and competitive advantage, this study provides insight to latecomers in the turbulent environment on how to transfer knowledge within organizations to cultivate their competitive advantages.

The structure of this paper will be as follows. Section 2 presents the theoretical background of this study. Section 3 presents the model development and hypothesis development. Section 4 provides the research method, sample, and data collection. Section 5 presents the results of hypotheses developments. Section 6 presents the discussion, conclusion, limitations, and recommendations for further work.

\section{Theoretical Background}

\subsection{Definition of $S I$}

The relationship between SI and competitive advantage is investigated to understand improvising actions at various organizations' levels. Organizational improvisation is defined as the design and execution under time pressure as an alternative solution for companies to develop in turbulent and dynamic markets [12,22]. Companies adopt improvisational actions at various levels. Sometimes, they tend to improvise for strategic 
purposes partially because strategic planning could be problematic when organizations need to be creative, flexible, and, thusly, profitable [23]. The concept of SI is providing significant solutions on how to adapt and adjust to the ever-changing environment $[15,24]$.

For example, Perry [25] understands SI as a process framed by both freedom and restrictions that emphasize continuous actions and experimentations but not obsessive planning. Some scholars like Eisenhardt [26] take a different stand to suggest that the key for companies to adapt to the environment is the improvising decisions that are intime and creatively made by top management teams rather than bottom-up improvising tactics. More recently, scholars intend to approach this construct from learning perspectives by viewing SI as an alternative organizational learning process. In line with that, SI is understood as a new paradigm for fast learning [7,14]. The ability of decision-making teams to improvise would enable them to make novel strategic decisions capitalizing on emerging opportunities that will move organizations forward [27].

In this paper, SI is understood as a real-time learning process that is adopted by top managers or funding teams spontaneously and creatively to respond to and enact unforeseen threats and opportunities using resources at hand under time pressure. It is operationalized as the decision-makers' ability to respond to unanticipated situations effectively with novelty to solve problems or use opportunities [28]. It involves making creative decisions and actions outside the formal organization structure [14]. SI is seen as a behavioral strategy used by leaders to respond to uncertainty, time pressure, and resource insufficiency [29].

\subsection{Organizational Learning}

Studies of organizational learning began in the1950s. Argyris and Schon [30] was the first work in the management field that systemically presents organizational learning to identify and correct errors by rebuilding the hypothesis behind individuals' behaviors. After that, scholars from various disciplines interpreted the nature of organizational learning and proposed a lot of different models. The diversified studies can be summarized into three viewpoints.

Some are taking a System Dynamics viewpoint argue that organizational learning happens in individuals' minds or the structure of an organization. Learners have the active cognition to process information or adjust organizational behavior within the structural elements. Antonacopoulou [31] describes organizational learning as a process where individuals within the structure process information and change their behavior.

Unlike the system dynamics perspective that views organizational learning as a cognitive process in individuals' minds, some scholars-adopting a sociological perspectivepresent organizational learning as the combined effect of power structures and hierarchy, conflict, ideology, and rhetoric. Learning and knowledge come from interactions and dialogues between individuals in situated contexts. Easterby-Smith et al. [32] emphasize that organizational learning is the outcome of interactions among individuals in a specific social environment. A key aspect of learning in situated contexts is identity constructions through dialogues in a community of practice [33]. In other words, unique identities hold by organizations could affect the learning process.

Some scholars examine organizational learning from a strategy perspective focusing on the interaction between organization and environment and different levels of learning and knowledge networks to answer how firms gain a competitive advantage from learning $[14,34]$.

Others employ an understanding of organizational learning as information processing. Huber [35] suggests that organizational learning includes knowledge acquisition, information spreading, interpretation, and organizational memory. Scholars taking this perspective argue that organizational learning involves creating, preserving, and transferring knowledge. Stemming from the same vein, some scholars argue that the environmental scan ability of organizations is essentially the process of collecting information about events and relationships with the external environment to solve problems, that is, basically, a 
learning process [36]. When performing scanning activity, organizations engage in a cyclic process among information needs, seeking and use [37], which enables organizations to develop plans [38] and initiate strategic changes [39]. Although the specific process of organizational learning from a knowledge-based viewpoint differs, learning includes using the information within organizations to generate new knowledge and institutionalize new knowledge to gain competitive advantages.

Although scholars have approached organizational learning from different angles, it is agreed that the learning subjects are individuals and refer to teams and whole organizations in a sustainable perspective. The contents of learning are information and knowledge. Most importantly, the goal of learning is to enhance performance and generate sustainable competitive advantages.

\subsection{SI as a Learning Process}

In this study, we present SI as a short-term real-time learning activity [22] that happens at multiple levels in organizations to explain its impact on competitive advantage.

First, SI is perceived as a spontaneous reaction to the environment based on unpredicted real-time information [14] and action learning through which organizations constantly adjust and adapt to the environment [21,40-42] and assess their actions and modifications [16]. These actions are often affected by decision-makers' ability to handle think-on-their-feet responses to upcoming events. Decision-makers are forced to deviate from established frames of reference to perform intuitive learning due to fast-changing context and lack of information [20].

Second, like other forms of learning, SI brings novel outcomes to some extent for competitive advantage. During the SI process, organizational members jointly handle a task extemporaneously, on which shared experiences are created and interpreted in a highly situated context [43,44]. SI sometimes brings about new cognitive models to redefine the way members make sense of events [33], even changes the basic assumptions of organizations. More often, SI serves as behavioral learning when it relies on existing organizational routines and transforms them at the same time [18].

Third, SI could be an unanticipated scanning activity involving problem-solving searching and spontaneously information using. Companies constantly search for knowledge in order to sustain themselves. Companies will face a variety of problems that need to be solved urgently, and when the company's existing knowledge and capabilities cannot produce the required problem-solving methods, the company will need to use various channels to search for potentially useful knowledge to help the company solve the current problem [40]. The enterprise knowledge search behavior that occurs in this situation is problem-solving search [41]. Some of the problem-solving searchings can be planned first, yet in a dynamic environment, some of the searchings need to be done under time pressure. SI performance requires real-time information flow [15], which includes finding new information (i.e., potentially useful knowledge), sharing and using it at the same time. Therefore, SI could use unplanned real-time scanning.

Even though not all various forms of outcomes of SI actions can be preserved, it is argued that at the end of improvising learning, organizations could make new products and institutionalize novel processes into existed routines [22] or perform strategic changes [4,5]. In situations like such, SI affects knowledge integration at an organizational level [38]. These works imply that SI, like traditional organizational learning activities, could result in intuitive learning at the individuals' level and collective interpretation and integration at the organizational level [36].

\section{Model Development and Hypotheses}

Based on the above theoretical background, we developed a moderated mediation model (see Figure 1) that captures the relationship between SI, organizational memory, organizational identity strength, and competitive advantage. The model will be thoroughly discussed in the following section. 


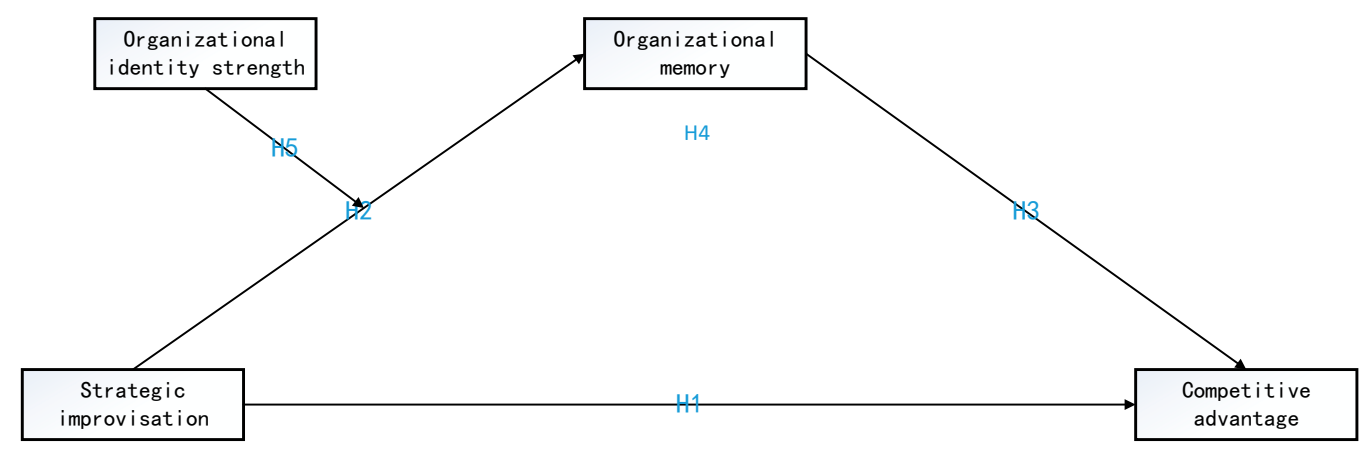

Figure 1. Conceptual model.

\subsection{Strategic Improvisation and Competitive Advantages}

In most organizations, the notion of competitive advantage is associated with economic performance, such as financial strength and good products or services [11]. Yet, some scholars like Foria, Cheung, and Herndon [10] argue that competitive advantage includes economic sustainability and social sustainability. Scholars of the resource-based view believe that competitive advantage uses existing resources to meet customer needs more effectively than competitors. In line with this, companies with competitive advantages could have excellent corporate performance in sustainable ways [45]. Similarly, from a dynamic capability viewpoint, having a competitive advantage means that in a complex dynamic environment, enterprises can continuously integrate internal and external resources and reshape resources multiple times to form core capabilities that are difficult to imitate [46]. Companies that possess competitive advantages could also indicate that they are able to use fewer resources to create more value. In this article, competitive advantage is understood as companies' characteristics that make them respond quickly to market changes and have higher than average performance in terms of resource integration, supply chain collaboration, and innovation capabilities.

Previous studies have made efforts to examine the relationship between SI and firms' competitive advantages. Ahmad, Arshad, and Marchalina [47]—using data collected from government-linked companies in Malaysia-argue that strategic improvisation and talent management are positively related to companies' competencies and firm's performance. Similarly, Mahmood and Baker [9] argue that strategic improvisation has a strong positive relationship with SME's performance with high entrepreneurial self-efficacy. Adomako, Opoku, and Frimpong [48] also suggest that SI in setups can bring higher performance under a positive moderating effect of financial resource capabilities and institutional support levels. Based on prior work, this paper argues that firms could gain competitive advantages from SI; therefore, proposing the first hypotheses:

Hypothesis 1. Strategic improvisation has a positive effect on firms' competitive advantages.

\subsection{SI as a Learning Activity: The Mediating Role of Organizational Memory}

SI understood as a fast learning activity is adopted by organizations as a real-time response $[17,27]$. SI happens under time pressure where composition and execution converge, and the narrower the time gap is, the more extemporaneous the action is. Composition implies that there is a certain degree of creativity involved in SI [12,48,49]. Besides, when improvising, organizations need to use whatever resources are at hand. In other words, SI is the action that organizations adopt to use resources within the organization created to generate new knowledge. From a knowledge-based viewpoint, organizational learning is understood as information processing that includes using the information within organizations to generate new knowledge and institutionalize new knowledge to gain competitive advantages [35,50]. As a result, SI could be an alternative way of learning.

In this paper, organizational learning is defined as the process of creating, preserving, and transferring knowledge, which includes knowledge acquisition, information spreading, 
interpretation, and organizational memory [51]. Organizational memory in this process is perceived as the aggregation of historical information that could guide companies to make decisions at all levels [52]. It is suggested that organizational memory covers organizational beliefs, knowledge, values, and stories [53], and it can be seen as form and informal knowledge assets [54,55]. Anderson [56] classifies organizational memory into procedural memory and declarative memory. Procedural memory is about how to do things, which usually includes skill and routine organization. Declarative memory is particular in that facilities are applying knowledge in similar contexts, novel understanding environment, and predicting outcomes. In the form of knowledge, organizational memory is considered a prerequisite for information technology to support knowledge management. Enterprises without organizational memory precipitation will not be able to carry out effective knowledge management.

It is suggested that improvisation could influence organizational memory formation over time [7]. Organizational evolution and the trial-and-error learning model suggest that random variations in real practice could bring unforeseen advantages. Companies could learn from those good outcomes and institutionalize them into organizational memory [18]. Cyert and March [41] describe this process as "unplanned adaptation". Instead of seemingly repeating successful improvising action, organizations can take one step further by making inferences beyond single-loop learning to guide actions in the coming future. Finally, some scholars believe that the process of performing and making observations of the outcomes could lead to deeper learning of explanations $[50,57]$. As a result, we predict that:

Hypothesis 2. Strategic improvisation behaviors can enrich organizational memory.

Previous studies adopting a knowledge-based view have demonstrated that organizational memory positively affects companies' competitive advantages. For example, Stein [58] proposes that organizational memory can promote organizational development by helping managers maintain strategic direction for a long time, helping new employees acquire skills faster, promoting organizational learning, and strengthening organizational identity. Moorman and Miner [53] suggest that the interpretation of past information and the implementation of R \& D practices can help promote new products. Consequently, we predict that:

Hypothesis 3. Organizational memory can affect firms' competitive advantages positively.

Along with the organization's learning process progressing, knowledge creation and knowledge management capabilities will be improved, and organizational memory in the form of heterogeneous characteristics knowledge will gradually accumulate, which ultimately promotes organizational performance improvement $[59,60]$. Organizational memory, as part of organizational learning, could influence outcomes of SI. Take the famous Honda case, for example. Honda planned to sell large motorcycles to the US market, yet Americans preferred to buying smaller Supercubs instead. Facing the unexpected challenge, Honda improvised to introduce small Supercubs in sports shops, and this action gradually became a piece of procedural memory and eventually reshaped the marketing strategy, which led to a big success. Hence, we predict that:

Hypothesis 4. Organizational memory mediates a positive relationship between strategic improvisation and firms' competitive advantages.

\subsection{The Moderating Role of Organizational Identity Strength}

Organizational identity is defined as the collective sense of who we are as an organization with central, enduring, and distinctive (CED) elements [61,62]. Organizational identity is perceived in individuals' cognitions $[63,64]$ and linked to how they make sense of and respond to daily practices [65]. Previous studies demonstrated that organizational 
identity could affect organizational culture, communicative activity [66,67], and even firm strategy [68].

Organizational identity strength reflects how its members perceive the identity as special or unique [69]. Each individual member has different perceptions of who they are as an organizational member. Consequently, organizational identity strength reflects how deeply and widely individuals' identity perceptions are held and shared [70], as presented in the individuals' sense of their organization's history, traditions, symbols, practices, and philosophy [65]. Organizational members are curial in the conceptualization, negotiation, and transformation of organizational identity [71]. On the one hand, maintaining the current organizational identity can be sustainable when members deeply believe in it. On the other, there needs to be a consensus between members about these deep-rooted beliefs. Only in the presence of these two aspects can organizational identity be considered strong [70]. Individuals' collective sense-making and beliefs of their identity as members of organizations could bring various organizational outcomes.

Strong organizational identity could affect organizations in terms of daily practices and organizational outcomes. Albert and Whetten [61] argue that when members hold a strong belief in their current organizational identity, it presents a coherent image to external audiences. Such a unified image could enable organizations to gain legitimacy from the external environment [72]. Further, since organizational identity lies at the core of strategy formation and execution, consensus and strength of organizational identity beliefs would imply members' acceptance and ownership of organizational goals and actions. Organizations with a strong organizational identity would pursue their goals through concerted efforts of members. Congruence in organizational identity perceptions among members also reduces the possibility of multiplicity and conflict in organizational identity.

The learning process could be seen as organizations' practice of adjusting and processing information to institutionalize experience within organizations [73,74]. Hence, making the outcomes from SI into organizational memory is also a process of institutionalizing unexpected knowledge within organizational settings. It is argued that a stronger organizational identity implies that the whole organization moves towards one direction, and members present higher identification $[65,75]$. Therefore, the stronger the organizational identity is, the easier the process of evolving SI outcomes into organizational memory could be. In other words, organizational strength could moderate the relationship between SI and organizational memory. As a result, we propose that:

Hypothesis 5. Organizational identity strength acts as a first stage moderator of the mediated relationship between strategic improvisation and firms' competitive advantages.

This moderating effect is such that, in teams with high organizational identity strength, strategic improvisation will have a positive relationship with firms' competitive advantages through organizational memory, and, in teams with low organizational identity strength, strategic improvisation will have a negative relationship with firms' competitive advantages through organizational memory.

\section{Methods}

\subsection{Sample and Data Collection}

Based on research questions, the study was conducted at an organizational level. We used a questionnaire survey to test our hypotheses. Our sample was selected from companies within Jiangsu Province, China. In Eastern China, Jiangsu borders Shanghai, Zhejiang, Anhui, and Shandong Provinces. Together with Shanghai and Zhejiang, Jiangsu formed the Yangtze River Delta urban agglomeration, one of the six largest urban agglomerations globally. The economic vitality of this region has always been among the best in China. Jiangsu Province's per capita GDP and regional index rank first in the country. According to the Fortune China 500 list, the number of Jiangsu's top 500 companies in China in 2019 was 31, an increase of 10 from 2014 [76]. However, due to the developed economy, the 
chances of unknown opportunities and challenges faced by Jiangsu enterprises are more significant, and the possibility of improvising decision-making by enterprise leaders is also greater. Questionnaires were sent to MBA students who study at a university in Nanjing. All of the students are either from the top management team in incumbent companies or a founding team from a new venture. In total, the researchers sent 280 surveys, and 224 valid responses were collected.

Descriptive characteristics of our samples are shown in Table 1. Since our research was conducted in China, we made the items indicate how big the firm is according to the "Statistics on the classification of large, medium, small and micro enterprises (2017)" and "National Economic Industry Classification" by the National Bureau of Statistics China. For example, by firm age, we mean the duration of the existence of a company. Firm size means how many employees are working for it.

Table 1. Sample distribution.

\begin{tabular}{cccc}
\hline Variables & Category & Frequency & Percentage (\%) \\
\hline \multirow{4}{*}{ Firm age } & 3 years & 12 & 5.31 \\
& $3 \sim 8$ years & 63 & 28.21 \\
& $8 \sim 15$ years & 76 & 34.19 \\
& $\geq 15$ years & 73 & 32.48 \\
\hline \multirow{5}{*}{ Firm size } & $<50$ & 69 & 30.80 \\
& $50 \sim 300$ & 74 & 33.04 \\
& $300 \sim 1000$ & 21 & 9.38 \\
Industry & $>1000$ & 60 & 26.79 \\
& Agriculture & 6 & 2.56 \\
& Manufacturing & 103 & 46.15 \\
& Services & 115 & 51.29 \\
\hline \multirow{3}{*}{ Ownership } & State-owned & 63 & 28.13 \\
& Collective & 34 & 15.18 \\
& Private & 105 & 46.88 \\
& Jointly owned & 14 & 6.25 \\
& Foreign-funded & 8 & 3.57 \\
\hline
\end{tabular}

\subsection{Measures}

Established measures from previous literature were adopted in this study. All measures were assessed with a seven-point Likert scale ranging from 1 (totally disagree) to 7 (totally agree). All the English items were translated into Chinese and then translated back to English to ensure translation accuracy.

The independent variable was strategic improvisation (SI), which was measured by the scale from Vera and Crossan [14] with a Cronbach's alpha of 0.975. The dependent variable was a competitive advantage (CA), which was measure by the scale developed by Richardson (2006) with a Cronbach's alpha of 0.894 [77]. The mediator was organizational memory (OM), which was measured by the scale developed by Wang, Wang, and Zhao [78] with a Cronbach's alpha of 0.813 . The moderator is organizational identity strength (OIDS), which was measured by the scale developed by Smids, Pruyn, and Van Riel [79] with a Cronbach's alpha of 0.912. The Cronbach's alpha of each scale was over 0.7, which demonstrated high reliability. Each item was measuring related constructs that are presented in Table 2.

In terms of control variables, after reviewing the literature, we included four variables that affect SI. These variables included firm size, firm age, type of industries firms belong to, and ownership type [80]. All the control variables were measured as independent variables in model analysis. Respondents were invited to choose the best-related description before they answer the questionnaire. 
Table 2. Constructs, measurement items, and loadings.

\begin{tabular}{|c|c|c|c|c|}
\hline Variables/Items & $\alpha$ & AVE & CR & Loading \\
\hline Strategic improvisation (SI) & 0.975 & 0.641 & 0.926 & \\
\hline The team deals with unanticipated events on the spot & & & & 0.852 \\
\hline Team members think on their feet when carrying out actions & & & & 0.840 \\
\hline The team responds at the moment to unexpected problems & & & & 0.783 \\
\hline The team tries new approaches to problems & & & & 0.790 \\
\hline The team identifies opportunities for new work processes & & & & 0.792 \\
\hline The team takes risks in terms of producing new ideas in doing its job & & & & 0.738 \\
\hline The team demonstrates originality in its work & & & & 0.800 \\
\hline Competitive advantages (CA) & 0.894 & 0.659 & 0.92 & \\
\hline $\begin{array}{c}\text { Compared with competitors, our company can provide customers with products or } \\
\text { services at a lower cost }\end{array}$ & & & & 0.683 \\
\hline $\begin{array}{l}\text { Compared with competitors, our company can provide customers with } \\
\text { multi-functional and high-performance products or services }\end{array}$ & & & & 0.809 \\
\hline $\begin{array}{l}\text { Compared with competitors, our company can execute the operation process in a } \\
\text { faster and more effective way }\end{array}$ & & & & 0.825 \\
\hline $\begin{array}{l}\text { Our company can flexibly adapt to the rapidly changing market and react faster } \\
\text { than opponents }\end{array}$ & & & & 0.875 \\
\hline Compared with competitors, our company pay more attention to customers' needs & & & & 0.825 \\
\hline Compared with competitors, our company's market share has grown faster & & & & 0.841 \\
\hline Organizational memory (OM) & 0.813 & 0.642 & 0.877 & \\
\hline $\begin{array}{c}\text { Knowledge and information of the company are indicated within the company's } \\
\text { structure, system, and procedures }\end{array}$ & & & & 0.772 \\
\hline Knowledge and information of the company are shown in the company's database & & & & 0.724 \\
\hline The company's culture contains creativity and how we do things & & & & 0.847 \\
\hline The company regards patents and licenses as an effective way to store knowledge & & & & 0.855 \\
\hline Organizational identity strength (OIDS) & 0.813 & 0.742 & 0.935 & \\
\hline I feel strong ties with the company & & & & 0.845 \\
\hline I experience a strong sense of belonging to the company & & & & 0.855 \\
\hline I feel proud to work for the company & & & & 0.906 \\
\hline I am sufficiently acknowledged in the company & & & & 0.843 \\
\hline I am glad to be a member of the company & & & & 0.857 \\
\hline
\end{tabular}

\subsection{Correlations}

Table 3 presents the correlations between all variables. The result shows that CA was positively related to SI

Table 3. Correlations of all variables $(\mathrm{N}=224)$.

\begin{tabular}{cccccccc}
\hline Variables & $\mathbf{1}$ & $\mathbf{2}$ & $\mathbf{3}$ & $\mathbf{4}$ & $\mathbf{5}$ & $\mathbf{6}$ & $\mathbf{7}$ \\
\hline Ownership & & & & & & & \\
Industry & -0.003 & & & & & & \\
Firm age & $-0.248^{* *}$ & -0.025 & & & & & \\
Firm size & $-0.293^{* *}$ & 0.058 & $0.586^{* *}$ & & & \\
SI & 0.119 & -0.072 & 0.049 & -0.038 & 0.650 & & \\
CA & 0.011 & -0.034 & -0.111 & -0.096 & $0.470^{* * *}$ & 0.659 & 0.642 \\
OM & -0.037 & 0.084 & -0.026 & 0.109 & $0.429^{* *}$ & $0.574^{* * *}$ & $0.620^{* * *}$ \\
OIDS & 0.043 & -0.090 & 0.014 & 0.078 & $0.609^{* *}$ & $0.671^{* *}$ & 0.742 \\
\hline
\end{tabular}

Note: ${ }^{* * *}$ means significance level at $<0.001 ;{ }^{* *}$ means significance level at $<0.01$. 


\subsection{Common Method Bias}

We minimized common method bias mainly by two means. First, Harman's onefactor test was adopted [81]. The result of Harman's one-factor test showed that all factors explained $68.628 \%$ of the total variation, while the first factor only accounted for $45.618 \%$ of the variation, which was less than the $50 \%$ threshold (see Table 4). This meant that the homology method bias of this study was not a concern [81].

Table 4. Total variation explained.

\begin{tabular}{ccccccc}
\hline \multirow{2}{*}{ Factor } & \multicolumn{3}{c}{ Initial Eigenvalues } & \multicolumn{3}{c}{ Extract the Sum of Squares and Load } \\
\cline { 2 - 6 } & Total & & \multicolumn{3}{c}{ Total } \\
\hline 1 & 9.580 & 45.618 & 45.618 & 9.580 & 45.618 & 45.618 \\
2 & 2.281 & 10.861 & 56.480 & 2.281 & 10.861 & 56.480 \\
3 & 1.436 & 6.836 & 63.315 & 1.436 & 6.836 & 63.315 \\
4 & 1.116 & 5.313 & 68.628 & 1.116 & 5.313 & 68.628 \\
\hline
\end{tabular}

Second, we used MPlus to construct a factor model that did not include a standard method (M1) and a factor model that included a standard method (M2) for testing since some consider Harman's one-factor test may not be convincing (see Table 5). Table 5 demonstrates that the degree of fit of the model after adding the common method factor was not significantly different from that of the model without the common method factor. Therefore, it can be considered that the research conclusions drawn by the direct effect were not subject to the standard method bias influences.

Table 5. Results of a one-factor model.

\begin{tabular}{cccccccc}
\hline Model & $\chi^{2}$ & df & $\chi^{2} / \mathbf{d f}$ & CFI & IFI & RMSEA & SRMR \\
\hline M1 & 445.635 & 188 & 2.370 & 0.923 & 0.924 & 0.078 & 0.059 \\
\hline M2 & 356.386 & 166 & 2.147 & 0.943 & 0.944 & 0.072 & 0.053 \\
\hline
\end{tabular}

\section{Results}

We adopted a hierarchical regression to test the hypotheses. Following standard procedure, all variables were entered sequentially to determine whether the next highorder interactions account for a statistically significant difference in the total explained variance [82]. We started with all the controls, followed by adding the independent variables to test direct effects. Then, we added the mediator (OM) and moderator (OIDS) to test the rest of our hypotheses.

\subsection{Direct Effect Test}

The regression results of the direct effects are presented in Table 6 . First, the regression results showed that SI was positively related to CA $(\beta=0.555 ; p<0.001)$. Model M1 demonstrated that the model interpretation strength was improved after the variable SI was added on the basis of the control variables (the modified $\mathrm{R} 2=0.229 ; \Delta \mathrm{R} 2=0.231$ ). Therefore, $\mathrm{H} 1$ is supported.

Second, OM affected CA positively $(\beta=0.555 ; p<0.001)$. Model M2 demonstrated that the model interpretation strength was improved after adding the variable OM (the modified $\mathrm{R} 2=0.346 ; \Delta \mathrm{R} 2=0.345)$. Therefore, $\mathrm{H} 2$ is supported.

Third, OM was positively affected by SI $(\beta=0.529 ; p<0.001)$. Model M4 demonstrated that the model interpretation strength was improved after the variable SI is added based on Model M3 (the modified R2 $=0.220 ; \Delta R 2=0.208$ ). Therefore, $H 3$ is supported. 
Table 6. Regression results of direct effects.

\begin{tabular}{|c|c|c|c|c|c|}
\hline \multirow{2}{*}{$\begin{array}{c}\text { Dependent } \\
\text { Variables }\end{array}$} & \multicolumn{3}{|c|}{ CA } & \multicolumn{2}{|c|}{ OM } \\
\hline & Mo & M1 & M2 & M3 & M4 \\
\hline ownership & -0.027 & -0.093 & -0.016 & -0.019 & -0.081 \\
\hline Firm age & -0.063 & -0.104 & -0.007 & -0.095 & -0.133 * \\
\hline Firm size & -0.031 & -0.012 & -0.097 & 0.111 * & $0.130 * *$ \\
\hline Industry & -0.010 & -0.001 & -0.022 & 0.020 & 0.039 \\
\hline SI & & $0.555^{* * *}$ & & & $0.529^{* * *}$ \\
\hline $\mathrm{OM}$ & & & $0.593^{* * *}$ & & \\
\hline $\mathrm{R} 2$ & 0.016 & 0.246 & 0.361 & 0.030 & 0.237 \\
\hline Modified R2 & -0.002 & $0.229^{* * *}$ & $0.346^{* * *}$ & 0.012 & $0.220^{* * *}$ \\
\hline$\Delta R 2$ & & 0.231 & 0.345 & & 0.208 \\
\hline $\mathrm{F}$ & 0.871 & 14.244 & 24.599 & 1.666 & 13.564 \\
\hline$\Delta \mathrm{F}$ & & $66.693^{* * *}$ & $117.653^{* * *}$ & & $59.379 * * *$ \\
\hline
\end{tabular}

Note: ${ }^{* * *}$ means significance level at $<0.001$; ${ }^{* *}$ means significance level at $<0.01 ;{ }^{*}$ means significance level at $<0.05$.

\subsection{Mediating Effect and Robustness Test}

We proposed that OM acts as a mediator in the relationship between SI and CA. As shown above, the positive relationships between SI and CA, SI and OM, OM and CA were well supported; therefore, when verifying the mediating effect of OM, we only needed to pay attention to the degree of change in the correlation between the independent variable and the dependent variable after $\mathrm{OM}$ is put into the regression equation (see Table 7).

Table 7. Results of mediation analysis.

\begin{tabular}{cccc}
\hline Dependent Variables & \multicolumn{3}{c}{ CA } \\
\hline & M0 & M1 & M5 \\
\hline Ownership & -0.027 & -0.093 & -0.054 \\
Firm age & -0.063 & -0.104 & -0.041 \\
Firm size & -0.031 & -0.012 & -0.072 \\
Industry & -0.010 & -0.001 & -0.014 \\
SI & & $0.555^{* * *}$ & $0.306^{* * *}$ \\
OM & & & $0.469^{* * *}$ \\
R2 & 0.016 & 0.246 & $0.416^{* *}$ \\
Modified R2 & -0.002 & $0.229^{* * *}$ & $0.400^{* * *}$ \\
$\Delta$ R2 & & 0.231 & 0.170 \\
F & 0.871 & 14.244 & 25.759 \\
$\Delta \mathrm{F}$ & & $66.693^{* * *}$ & $63.057^{* * *}$ \\
\hline
\end{tabular}

Note: ${ }^{* * *}$ means significance level at $<0.001$.

Mediation analysis indicated that OM partially mediated the relationship between SI and CA. Model M5 demonstrated that the positive effects of SI on CA were still significant after adding OM on the basis of Model M1. Also, the regression coefficient $\beta$ was reduced from $0.555(p<0.001)$ to $0.306(p<0.01)$. At the same time, OM had a significant impact on CA $(B=0.469, p<0.01)$. This meant that OM partially mediated the positive relationship between SI and CA; therefore, H4 is supported.

We further tested the robustness of the mediation effect based on the regression analysis results of the mediation effect. As shown in Table 8, the OM partially mediated the positive relationship between SI and CA. 
Table 8. Results of robustness test of mediating effect.

\begin{tabular}{ccccccc}
\hline \multicolumn{2}{c}{ Independent Variable: SI } & Effect & Boot SE & $p$ & Boot 95\% CI \\
\hline \multirow{3}{*}{ Effect } & Total effect & Total & 0.555 & 0.068 & $0.000 * * *$ & {$[0.421,0.689]$} \\
& Direct effect & & 0.306 & 0.068 & $0.010 *$ & {$[0.173,0.440]$} \\
& Indirect effect & Total & 0.217 & 0.041 & & {$[0.148,0.305]$} \\
& & OM & 0.217 & 0.039 & & {$[0.147,0.297]$} \\
\hline
\end{tabular}

Note: ${ }^{* * *}$ means significance level at $<0.001 ; *$ means significance level at $<0.01$.

\subsection{Moderating Effect and Robustness Test}

We predicted that OIDS positively moderated the relationship between SI and OM, yet empirical results (Table 9) demonstrated otherwise. Model M7 showed that after adding SI*OIDS into model M6, the effect was not significant $(\beta=109, p>0.05)$. This means that H5 is unsupported.

Table 9. Results of Moderation Analysis.

\begin{tabular}{ccc}
\hline \multirow{2}{*}{ Dependent Variable } & \multicolumn{2}{c}{ OM } \\
\cline { 2 - 3 } & M6 & M7 \\
\hline Ownership & -0.083 & -0.058 \\
Firm age & $-0.118^{* *}$ & $-0.126^{* *}$ \\
Firm size & $0.115^{* *}$ & $0.140^{* * *}$ \\
Industry & 0.027 & $0.032^{*}$ \\
SI & & 0.086 \\
OIDS & & $0.571^{* *}$ \\
SI*OIDS & & 0.109 \\
R2 & 0.031 & 0.462 \\
Modified R2 & 0.014 & 0.445 \\
$\Delta$ R2 & & 0.000 \\
F & 1.774 & 26.548 \\
$\Delta$ F & & 0.173
\end{tabular}

Note: ${ }^{* * *}$ means significance level at $<0.001 ;{ }^{* *}$ means significance level at $<0.01 ;{ }^{*}$ means significance level at $<0.05$.

We further tested the robustness of the proposed moderation effect of OIDS via a simple slop test and slop difference test (Table 10, Figure 2). The result in Table 10 indicated that the high, low, and cross-group effects were not significant, so the positive moderation effect of OIDS did not exist.

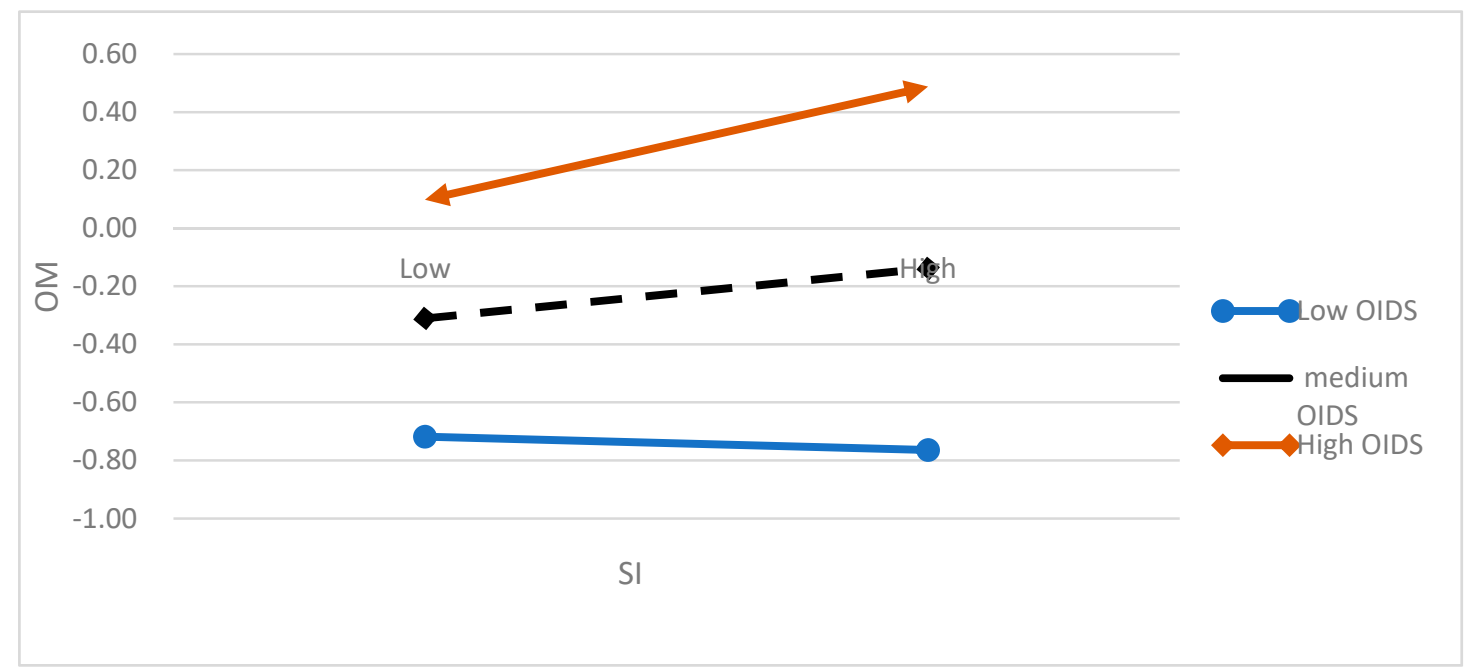

Figure 2. Moderation effect. 
Table 10. Results of the robustness test of moderating analysis.

\begin{tabular}{ccccc}
\hline Path & Level of Moderating & Effect Size & $p$ & SE \\
\hline \multirow{3}{*}{ SI $\rightarrow$ OM } & High & 0.159 & 0.087 & 0.092 \\
& Low & 0.103 & 0.171 & 0.075 \\
& Cross-group & 0.131 & 0.086 & 0.076 \\
\hline
\end{tabular}

\section{Discussion and Conclusions}

\subsection{Key Findings}

This study develops an integrated model linking SI, OM, and competitive advantage. Based on 224 questionnaire responses, we found that SI is positively related to CA, and OM partially mediates this relationship positively. This finding answers how SI brings CA to companies in a good way.

We also intended to address the question of why such effects appear to differ among companies by investigating the moderating role of OIDS in the relationship between SI and $\mathrm{OM}$; however, the related hypothesis was unproven. The result of the regression analysis showed that the moderating effect of OIDS on the relationship between SI and OM is not significant. This finding indicates that a stronger organizational identity may not facilitate companies to learn from SI actions and further transfer into OM. We suppose that there are mainly two reasons for this unexpected finding.

First, from a learning perspective, as a real-time learning activity, SI may be repeated several times but produce no systematic outcomes that can be used in the future [22]. In this sense, knowledge generated from SI actions may not be institutionalized into OM and cannot bring CA to companies in the next step.

Second, the statistically insignificant moderating effects of OIDS on the relationship between SI and OM may be attributed to the potential positive and negative influences it confers. Strong OIDS may bring up oneness via depersonalization and, in turn, impede new knowledge retention [83]. Since SI actions usually involve novelty, then transferring outcomes of SI actions into OM for organizations is to add new things into old books, which could be actions of creating new knowledge to some extent. During this process, the oneness that stems from strong OIDS may be problematic.

Additionally, the unit system in China's context may contribute to an unexpected result. The unit system in state-owned companies in China has been going through profound transformation for decades. It involves the game between the state and the market in the relationship with companies $[84,85]$. Although the degree of state control over enterprises has gradually decreased after the restructuring, and the role of market regulation has become more significant, yet the strong institution in China still has a great impact on enterprise activities [85]. The influence of the state on the resource allocation and personnel disposal of enterprises is crucial. Some managers adopt the governance technology of equal pay for the same post in such an institutional environment. Therefore, the organizational identity formed by enterprise personnel shows the characteristics of resource dependence [85]. In other words, the strength of organizational identity perceived by people depends on the number of resources they get in the company. At the same time, the governance of equal pay for the same post adopted by companies, to some extent, ignores the potential role of employees' differentiated knowledge in their work, so it is not conducive to the creation and sharing of knowledge within the enterprise. Therefore, the organizational identity formed in this environment may also hinder the formation of new knowledge. As a result, Future studies to explore this ambiguous issue are welcomely encouraged.

\subsection{Theoretical Contribution}

This study contributes to the existing literature theoretically in two folds. First, it enriches understandings of how companies gain CA in a turbulent environment to become sustainable. The traditional resource-based view suggested that companies can gain CA 
when they possess valuable, rare, imperfectly imitable and non-substituable (VRIN) resources and capabilities $[45,86]$. On the contrary, our findings provide empirical evidence supporting that companies could get CA by adopting SI actions, which have been characterized by bricolage in nature. Companies often tend to adopt SI actions when they are resource-constrained or lack specific capabilities when facing unexpected challenges. This phenomenon is even more prevalent in microenterprises that make profits and solve socio-economic problems related to poverty [87]. As for economic growth, previous studies believe that microenterprises can contribute to low-cost employment [88] and wealth generation in the nations' economic system, especially in developing countries [89,90]. Our findings suggest that companies short in resources or capability-limited like microenterprises could also cultivate their own CA. This finding makes up for the deficiency of resource-based view to some extent.

Also, based on a resource-based view, our findings shed light on the sustainable development literature. Sustainable development is a complex issue involving multidisciplines. In the management field, some studies have been done to address issues on how firms can contribute to reduce poverty $[87,89]$, balancing economic growth and the environment, eliminating inequality $[88,90]$, and so on. This paper contributes to achieving SDG 8 and 12. To be more specific, in terms of SDG8, our finding indicates that companies can sustain and thrive in a dynamic environment by adopting SI actions, and they can provide more decent jobs, especially in developing countries. As for SDG 12, we performed SI actions to bricolage resources and creatively used them. By doing so, firms could consume fewer resources to create more value by improving resource utilization and reducing redundant resources.

To take one step further, although a few theoretical studies proceeded SI as a real-time learning activity that could bring benefits to companies [2,91], little progress of how this learning process influences CA generation in a specific form is more directly understood and empirically examined. Thus, our study narrows the gap by proposing and examining $\mathrm{OM}$ as a novel mediator with a focus on OIDS as an internal moderator. This finding enriches organizational learning literature by suggesting a learning mechanism of gaining CA within organizations.

Second, our study adds insights into SI literature. To date, much of the works on SI have focused on analyzing antecedents of SI $[47,92,93]$ in order to understand how SI happened, but one hitherto understudied aspect is the mechanism of its effect on organizations. Some studies tended to examine contingent factors outside organizations such as environment turbulence and information flow. Our study unpacks a learning mechanism between SI and CA inside organizations by investigating OM's mediating role. Our study also echoes knowledge management research that proposed improvisation positively contributes to knowledge transfer inside organizations $[43,44]$ by providing empirical evidence presenting that $\mathrm{SI}$ is positively related to $\mathrm{OM}$, which is a crucial component that stores knowledge in organizations.

Furthermore, since environmental scanning is also a type of organizational learning which could reconstruct organizational knowledge [2], we could argue that SI is real-time scanning with little planning. To sustain, companies need to search for knowledge to solve problems [40]. SI could be understood as unanticipated real-time problem-solving searching action due to its unplanned and creative nature. Since SI actions can enrich OM, then as a searching action, it could provide companies with more possibilities to reconstruct organizational knowledge. In this way, we enrich the study on organizational searching research by pointing out a unique searching type. Additionally, prior studies tended to consider OM as an antecedent that triggers SI actions [7], and our study suggests that OM could be the outcome of SI through which companies gain CA. This finding broadens the understanding of the relationship between SI and OM. 


\subsection{Pratical Contribution}

Our study also provides some practical insights for companies in a turbulent environment in a sustainable way. First, since our empirical findings demonstrate that SI could generate CA, companies need to pay attention to SI actions intentionally. For example, latecomers and setups could intentionally enhance their SI capabilities since they may lack other forms of external resources at the beginning. SI capabilities, on the other hand, could be learned and cultivated internally. Hence, we suggest leaders promote improvisations in firms at all levels and provide training or other learning opportunities for members to master related skills.

Second, in terms of generating new OM that can be used for future decision-making, it would be of great significance if members reflect collectively after performing SI to facilitate the processes of OM formation. OM evolved from SI can be highly situated, making the costs of imitating that part of knowledge very high. In this sense, OM comes from SI is extremely valuable to companies because it is novel and useful but builds up high barriers to protect from competitors' imitation. As a result, we highly recommend leaders establish mechanisms that could facilitate the evolution processes from SI to OM.

Third, as for corporate sustainability, we would like to draw decision makers' attention to rethinking resource consumption and production patterns. Since the characters of SI actions include bricolage resources and solve problems in a novel manner, we encourage decision-makers to re-examine the company's existing and required resources and carefully consider whether the company's problems can only be solved by consuming more resources. Enterprises should re-integrate existing resources and use innovative methods to solve production problems by collaborating with all stakeholders, with the help of organizational learning, rather than relying solely on obtaining more resources.

\subsection{Limitations and Future Direction}

For companies to become sustainable in the ever-changing environment, they are often required to adopt improvising responses to certain unpredicted events and sometimes need to improvise strategically to survive or thrive. As improvisation can be double-edged, it is rather curial for companies to know the mechanism of how SI contributes to CA. Our study developed a moderated mediation model to unpack the black box between SI and CA. We presented empirical evidence demonstrating that SI adopted by companies could bring CA, and OM positively mediates this relationship. Thus, our study contributes to the existing literature by making up for the deficiency of traditional RBV to some extent, enriching the understanding of how companies gain CA in a turbulent environment from a learning perspective and adding insights into SI studies by examining the relationship between SI and OM.

Our study inevitably has some limitations. First, although it has been confirmed that there are positive learning effects of SI on organizations, the organizational learning process cannot be easily measured due to its various forms. Except for OM, there may be other mediators between SI and CA. Thus, our studies leave open space for future research to invest in other learning mechanisms contributing to CA generation. Second, our study used data collected from a certain area in China, which is very geographically specific. Hence, future studies could take samples from other countries to discuss this issue in different contexts. Finally, the moderating effect of OIDS is not proven in our study; therefore, it would be fruitful for further studies to test other contingent factors inside or outside organizations to extend the boundaries of existing literature. Another interesting research avenue is that there is an emerging perspective on the interactive nature of learning and organizational memory $[94,95]$. Since a single party cannot achieve corporate sustainability, the interacting mechanism among various stakeholders during the evolution from SI to OM can affect how firms consume resources and produce could be important. 
Author Contributions: Conceptualization: S.Y.; Methodology: S.Y. and Y.Z.; Data analysis: J.Y., X.Y. and A.M.; Review and editing: A.M. and S.Y. All authors have read and agreed to the published version of the manuscript.

Funding: This research was funded by Decision-making Consulting Base, Jiangsu, China. Grant number: 20SSL126.

Institutional Review Board Statement: Not applicable.

Informed Consent Statement: Not applicable.

Data Availability Statement: The data is not publicly available due to privacy.

Conflicts of Interest: The authors declare no conflict of interest.

\section{References}

1. Burns, T.; Stalker, G.M. The Management of Innovation; Tavistock Publications: London, UK, 1994.

2. Crossan, M.M.; Lane, H.W.; White, R.E.; Klus, L. The improvising organization: Where planning meets opportunity. Organ. Dyn. 1996, 24, 20-35. [CrossRef]

3. Grinyer, P.H.; Nornburn, J.G. Planning for existing markets: Perceptions of executives and financial performance. J. R. Stat. Soc. Ser. A 1975, 138, 70-97. [CrossRef]

4. Baker, T.; Miner, A.S.; Eesley, D.T. Improvising firms: Bricolage, account giving and improvisational competencies in the founding process. Res. Policy 2003, 32, 255-276. [CrossRef]

5. Best, S.; Gooderham, P. Improvisation: A legitimate strategy in the face of adversity. Small Enterp. Res. 2015, 22, 49-68. [CrossRef]

6. Eisenhardt, K.M.; Tabrizi, B.N. Accelerating Adaptive Processes: Product Innovation in the Global Computer Industry. Adm. Sci. Q. 1995, 40, 84. [CrossRef]

7. Moorman, C.; Miner, A.S. Organizational improvisation and organizational memory. Acad. Manag. Rev. 1998, $23,698-723$. [CrossRef]

8. Ibrahim, N.A.; Mahmood, R.; Bakar, M.S. Linking strategic improvisation and entrepreneurial self-efficacy to corporate entrepreneurship in Nigerian higher education institutions (HEIs). Manag. Sci. Lett. 2016, 745-752. [CrossRef]

9. Mahmood, R.; Bakar, H.A. Examining strategic improvisation and performance relationship in the SMES: Moder-ating role of entrepreneurial self-Efficacy. Int. Bus. Manag. 2016, 10, 2535-2540.

10. Knudsen, J.S.; Moon, J. Corporate Social Responsibility as Mutual Governance: International Interactions of Government, Civil Society and Business. In Proceedings of the Academy of Management Annual Meeting 2012, Boston, MA, USA, 3-7 August 2012.

11. Wang, H.M.; Huo, C.H. Enterprise ethics and competitive advantages. Theory Horiz. 2006, 10, 51-52.

12. Moorman, C.; Miner, A.S. The convergence of planning and execution: Improvisation in new product development. J. Mark. 1998, 62, 1-20. [CrossRef]

13. Grøtan, T.O.; Størseth, F.; Rø, M.H.; Skjerve, A.B. Resilience, Adaptation and Improvisation-increasing resilience by organising for successful improvisation. In Proceedings of the 3rd Symposium on Resilience Engineering, Antibes-Juan-les-Pins, France, 28-30 October 2008.

14. Vera, D.; Crossan, M. Improvisation and Innovative Performance in Teams. Organ. Sci. 2005, 16, 203-224. [CrossRef]

15. Hadida, A.L.; Tarvainen, W.; Rose, J. Organizational Improvisation: A Consolidating Review and Framework. Int. J. Manag. Rev. 2014, 17, 437-459. [CrossRef]

16. Chelariu, C.; Johnston, W.J.; Young, L. Learning to improvise, improvising to learn: A process of responding to complex environments. J. Bus. Res. 2002, 55, 141-147. [CrossRef]

17. Bergh, D.D.; Lim, N.K. Learning how to restructure: Absorptive capacity and improvisational views of restructuring actions and performance. Strateg. Manag. J. 2008, 29, 593-616. [CrossRef]

18. Feldman, M.S.; Pentland, B.T. Reconceptualizing Organizational Routines as a Source of Flexibility and Change. Adm. Sci. Q. 2003, 48, 94. [CrossRef]

19. Rerup, C.; Feldman, M.S. Routines as a Source of Change in Organizational Schemata: The Role of Trial-and-Error Learning. Acad. Manag. J. 2011, 54, 577-610. [CrossRef]

20. Crossan, M.M. Improvisation in Action. Organ. Sci. 1998, 9, 593-599. [CrossRef]

21. Cunha, M.P.E.; Neves, P.; Clegg, S.R.; Rego, A. Tales of the unexpected: Discussing improvisational learning. Manag. Learn. 2014, 46, 511-529. [CrossRef]

22. Miner, A.S.; Bassoff, P.; Moorman, C. Organizational Improvisation and Learning: A Field Study. Adm. Sci. Q. 2001, 46, 304. [CrossRef]

23. Slotegraaf, R.J.; Dickson, P.R. The paradox of a marketing planning capability. J. Acad. Mark. Sci. 2004, 32, 371-385. [CrossRef]

24. Hatinah, A.B.; Rosli, M.; Hasimah, I. Nurturing SME performance through knowledge management, learning orientation, strategic improvisation. In Proceedings of the 10th Annual London Business Research Conference, Imperial College, London, UK, 10-11 August 2015.

25. Perry, L.T. Strategic improvising: How to formulate and implement competitive strategies in concert. Organ. Dyn. 1992, 19, 51-64. 
26. Eisenhardt, K.M. Strategic Decisions and All That Jazz. Bus. Strat. Rev. 1997, 8, 1-3. [CrossRef]

27. Hmieleski, K.M.; Corbett, A.C.; Baron, R.A. Entrepreneurs' Improvisational Behavior and Firm Performance: A Study of Dispositional and Environmental Moderators. Strat. Entrep. J. 2013, 7, 138-150. [CrossRef]

28. Ibrahim, N.A.; Mahmood, R.; Baker, M.S. Strategic improvisation and HEIs performance: The moderating role of organizational culture. PSU Res. Rev. 2018, 2, 212-230. [CrossRef]

29. $\mathrm{Hu}, \mathrm{L} . ; \mathrm{Gu}, \mathrm{J} . ; \mathrm{Wu}, \mathrm{J} . ;$ Lado, A.A. Regulatory focus, environmental turbulence, and entrepreneur improvisation. Int. Entrep. Manag. J. 2017, 14, 129-148. [CrossRef]

30. Argyris, C.; Schön, D.A. Organizational Learning: A Theory of Action Perspective. Revista Española de Investigaciones Sociológicas 1997, 77-78, 345-348. [CrossRef]

31. Antonacopoulou, E.P. The relationship between individual and organizational learning: New evidence from managerial learning practices. Manag. Learn. 2006, 37, 455-473. [CrossRef]

32. Easterby-Smith, M.; Crossan, M.; Nicolini, D. Organizational learning: Debates past, presents and future. J. Manag. Stud. 2000, 37, 783-796. [CrossRef]

33. Bloch, M.; Lave, J.; Wenger, E. Situated Learning: Legitimate Peripheral Participation; Cambridge University Press: Cambridge, UK, 1991.

34. Hodge, B.J.; Anthony, W.P.; Gales, L.M. Organization Theory "A Strategic Approach"; Prentice Hall: Upper Saddle River, NJ, USA, 2003.

35. Huber, G.P. Organizational Learning: The Contributing Processes and the Literatures. Organ. Sci. 1991, 2, 88-115. [CrossRef]

36. Choo, C.W.; Auster, E. Environmental scanning: Acquisition and use of information by managers. Ann. Rev. Inf. Sci. Technol. 1993, 28, 279-314.

37. Choo, C.W. Environmental scanning as information seeking and organizational learning. Inf. Res. 2001, 7, 112.

38. Sharma, R.S.; Yang, Y.A. Hybrid Scenario Planning Methodology for Interactive Digital Media. Long Range Plan. 2015, 48, 412-429. [CrossRef]

39. Ben-Menahem, S.M.; Kwee, Z.; Volberda, H.W.; Bosch, F.A.V.D. Strategic Renewal Over Time: The Enabling Role of Potential Absorptive Capacity in Aligning Internal and External Rates of Change. Long Range Plan. 2013, 46, 216-235. [CrossRef]

40. Howells, J.; James, A.; Malik, K. The sourcing of technological knowledge: Distributed innovation processes and dynamic change. RED Manag. 2003, 33, 395-409. [CrossRef]

41. Cyert, R.M.; March, J.G. A Behavioral Theory of the Firm; Prentice-Hall: Englewood Cliffs, NJ, USA, 1963; Volume 2, pp. $169-187$.

42. Cunha, M.P.; Clegg, S. Improvisation in the learning organization. Learn. Organ. 2019, 26, 238-251. [CrossRef]

43. Krylova, K.O.; Vera, D.; Crossan, M. Knowledge transfer in knowledge-intensive organizations: The crucial role of improvisation in transferring and protecting knowledge. J. Knowl. Manag. 2016, 20, 1045-1064. [CrossRef]

44. Mohannak, K. Knowledge management challenges in small-and medium-sized enterprises. In Proceedings of the IFSAM 12th World Congress: Management in Crisis, Tokyo, Japan, 2-4 September 2014.

45. Barney, J. Firm Resources and Sustained Competitive Advantage. J. Manag. 1991, 17, 99-120. [CrossRef]

46. Wang, C.L.; Ahmed, P.K. Dynamic capabilities: A review and research agenda. Int. J. Manag. Rev. 2007, 9, 31-51. [CrossRef]

47. Ahmad, H.; Arshad, D.; Marchallina, L. Entrepreneurial Orientation, Strategic Improvisation, Talent Management and Firm Performance. PressAcademia 2015, 4, 92. [CrossRef]

48. Adomako, S.; Opoku, R.A.; Frimpong, K. Entrepreneurs' improvisational behavior and new venture performance: Firm-level and institutional contingencies. J. Bus. Res. 2018, 83, 10-18. [CrossRef]

49. Crossan, M.; Sorrenti, M. Making sense of improvisation. In Advances in Strategic Management; JAI Press: Greenwich, CT, USA, 1997; Volume 14, pp. 155-180.

50. Weick, K.E. The collapse of sense-making in organizations: The Mann Gulch disaster. Adm. Sci. Q. 1993, 38, 628. [CrossRef]

51. Garvin, D.A. Manufacturing Strategic Planning. Calif. Manag. Rev. 1993, 35, 85-106. [CrossRef]

52. Lant, T.K.; Argote, L. Organizational Learning: Creating, Retaining, and Transferring Knowledge. Adm. Sci. Q. 2000, 45, 622. [CrossRef]

53. Walsh, J.P.; Ungson, G.R. Organizational Memory. In Knowledge in Organisations; Butterworth-Heinemann: Waltham, MA, USA, 1997; pp. 177-212. [CrossRef]

54. Moorman, C.; Miner, A.S. The impact of organizational memory on new product performance and creativity. J. Mark. Res. 1997, 34, 91-106. [CrossRef]

55. Chen, L.; Yun, J. Foreign research on organizational memory: Review and future direction. Soc. Sci. Abroad 2014, 1, 53-61.

56. Anderson, J.R. The Adaptive Character of Thought; Psychology Press: Hove, UK, 1990.

57. March, J.G. Rationality, Foolishness, and Adaptive Intelligence. Strateg. Manag. J. 2006, 27, 201-214. [CrossRef]

58. Stein, E. Organization memory: Review of concepts and recommendations for management. Int. J. Inf. Manag. 1995, 15, 17-32. [CrossRef]

59. Cross, R.; Baird, L. Technology is not enough: Improving performance by building organizational memory. MIT Sloan Manag. Rev. 2000, 41, 69 .

60. Lee, W.-L.; Lai, M.-C.; Lin, L.-H.; Huang, H.-C. Value creation potential of individual and organizational memory in health care services. Expert Syst. Appl. 2011, 38, 10658-10664. [CrossRef]

61. Albert, S.; Whetten, D. Organizational identity. Res. Organ. Behav. 1985, 7, 263-295. 
62. Albert, S.; Whetten, D.A. Organizational identity. In Organizational Identity: A Reader; Oxford University Press: Oxford, UK, 2004; pp. 89-118.

63. Dutton, J.E.; Dukerich, J.M. Keeping an eye on the mirror: Image and identity in organizational adaptation. Acad. Manag. J. 1991, 34, 517-554.

64. Gioia, D.A.; Schultz, M.; Corley, K.G. Organizational identity, image, and adaptive instability. Acad. Manag. Rev. 2000, 25 , 63-81. [CrossRef]

65. Gioia, D.A.; Thomas, J.B. Identity, image, and issue interpretation: Sense-making during strategic change in academia. Adm. Sci. Q. 1996, 41, 370-403. [CrossRef]

66. Hatch, M.J.; Schultz, M. The dynamics of organizational identity. Hum. Relat. 2002, 55, 989-1018. [CrossRef]

67. Huang-Horowitz, N.C.; Evans, S.K. Communicating Organizational Identity as Part of the Legitimation Process: A Case Study of Small Firms in an Emerging Field. Int. J. Bus. Commun. 2017, 57, 327-351. [CrossRef]

68. Livengood, R.S.; Reger, R.K. That's our turf! Identity domains and competitive dynamics. Acad. Manag. Rev. 2010, 35, 48-66.

69. Milliken, F.J. Perceiving and interpreting environmental change: An examination of college administrators 'interpretation of changing demographics. Acad. Manag. J. 1990, 33, 42-63.

70. Kreiner, G.E.; Ashforth, B.E. Evidence toward an expanded model of organizational identification. J. Organ. Behav. 2003, 25, 1-27. [CrossRef]

71. Ashforth, B.E.; Rogers, K.M.; Corley, K.G. Identity in Organizations: Exploring Cross-Level Dynamics. Organ. Sci. 2011, 22, 1144-1156. [CrossRef]

72. Price, K.N.; Gioia, D.A. The self-monitoring organization: Minimizing discrepancies among differing images of or-ganizational identity. Corp. Reputat. Rev. 2008, 11, 208-221. [CrossRef]

73. Shrivastava, P. A Typology of Organizational Learning Systems. J. Manag. Stud. 1983, 20, 7-28. [CrossRef]

74. Shrivastava, P. Principles of Emergency Planning and Management. Risk Manag. 2003, 5, 67. [CrossRef]

75. Kjærgaard, A.L. Organizational Identity and Strategy: An Empirical Study of Organizational Identity's Influence on the StrategyMaking Process. Int. Stud. Manag. Organ. 2009, 39, 50-69. [CrossRef]

76. A Brief Introduction of Jiangsu. (n.d.). Available online: http://www.js.gov.cn/col/col31359/index.html (accessed on 24 January 2020).

77. Richardson, T.R. Competitive Advantage: The Effect of Market Competition on the Formation of Strategy in Small Business School Higher Education. Ph.D. Thesis, University of Pennsylvania, Philadelphia, PA, USA, 2006.

78. Wang, Y.G.; Wang, N.; Zhao, H.W. Organizational memory, organizational learning and supplier innovation ca-pability: An empirical investigation in the context of outsourcing. Sci. Res. Manag. 2014, 35, 1-8.

79. Smidts, A.; Pruyn, A.T.H.; Van Riel, C.B. The impact of employee communication and perceived external prestige on organizational identification. Acad. Manag. J. 2001, 44, 1051-1062.

80. Connell, J.; Voola, R. Size does matter: Collaboration and competitive advantage within a manufacturing and en-gineering cluster. Int. J. Glob. Small Bus. 2010, 4, 61-72. [CrossRef]

81. Fuller, C.M.; Simmering, M.J.; Atinc, G.; Atinc, Y.; Babin, B.J. Common methods variance detection in business research. J. Bus. Res. 2016, 69, 3192-3198. [CrossRef]

82. Wiklund, J.; Shepherd, D. Entrepreneurial orientation and small business performance: A configurational approach. J. Bus. Ventur. 2005, 20, 71-91. [CrossRef]

83. Dukerich, J.M.; Kramer, R.M.; Parks, J.M. Identity in Organizations: Building Theory through Conversations. In Identity in Organizations: Building Theory through Conversations; Sage Publications: Thousand Oaks, CA, USA, 1998; pp. $245-256$.

84. Wang, Y.B. Organizational Identity in China; Social Science Academic Press: Beijing, China, 2012.

85. Zheng, Q.J. Identity and Politics of the Production; China Social Science Press: Beijing, China, 2015.

86. Ray, G.; Barney, J.B.; Muhanna, W.A. Capabilities, business processes, and competitive advantage: Choosing the dependent variable in empirical tests of the resource-based view. Strat. Manag. J. 2003, 25, 23-37. [CrossRef]

87. Mohiuddin, M.; Mazumder, M.N.H.; Al Mamun, A.; Su, Z. Evolution of social microenterprises from rural to the urban area: A study on income-generating micro-entrepreneurs in an urban context. Strat. Chang. 2020, 29, 435-446. [CrossRef]

88. Maniruzzaman, M. Role of Working Capital Finance in the Growth of SME Sector in Bangladesh. Int. J. New Technol. Res. 2017, 3, 263279.

89. Turyakira, P.; Kasimu, S.; Turyatunga, P.; Kimuli, S.N. The joint effect of firm capability and access to finance on firm performance among small businesses: A developing country perspective. Afr. J. Bus. Manag. 2019, 13, 198-206.

90. Musara, M.; Nieuwenhuizen, C. Informal sector entrepreneurship, individual entrepreneurial orientation and the emergence of entrepreneurial leadership. Afr. J. Manag. 2020, 6, 194-213. [CrossRef]

91. Xiang, Q.; Zhang, J.; Liu, H. Organisational improvisation as a path to new opportunity identification for incumbent firms: An organisational learning view. Innovation 2020, 22, 422-446. [CrossRef]

92. Hmieleski, K.M.; Corbett, A.C. Improvisation as a Framework for Investigating Entrepreneurial Action. In Academy of Management Best Paper Proceedings; Academy of Management: Briarcliff Manor, NY, USA, 2003; Volume 2003, pp. 1-6. [CrossRef]

93. Duxbury, T. Improvising entrepreneurship. Technol. Innov. Manag. Rev. 2014, 4, 22-26. [CrossRef] 
94. Fleming, L.; Sorenson, O. Technology as a complex adaptive system: Evidence from patent data. Res. Policy 2001, 30, 1019-1039. [CrossRef]

95. Foroughi, H.; Coraiola, D.M.; Rintamäki, J.; Mena, S.; Foster, W.M. Organizational Memory Studies. Organ. Stud. 2020, 41, 1725-1748. [CrossRef] 